\title{
Attenuation of Antibody Titers from 3 to 6 Months after the Second Dose of the BNT162b2 Vaccine Depends on Sex, with Age and Smoking Risk Factors for Lower Antibody Titers at 6 Months
}

\author{
Yushi Nomura ${ }^{1,2}$, Michiru Sawahata ${ }^{1,3, * \mathbb{D}}$, Yosikazu Nakamura ${ }^{4} \mathbb{D}$, Ryousuke Koike ${ }^{1,2}$, Otohiro Katsube ${ }^{1}$, \\ Koichi Hagiwara $^{3}$, Seiji Niho ${ }^{2}$, Norihiro Masuda ${ }^{5}$, Takaaki Tanaka ${ }^{6}$ and Kumiya Sugiyama ${ }^{1,7}$ (D)
}

1 Department of Respiratory Medicine and Clinical Immunology, National Hospital Organization Utsunomiya National Hospital, Utsunomiya 329-1193, Japan; uc.nomura@gmail.com (Y.N.);

ryou.k.1207@gmail.com (R.K.); 5okatsube@gmail.com (O.K.); sugiyama@dokkyomed.ac.jp (K.S.)

2 Department of Pulmonary Medicine and Clinical Immunology, Dokkyo Medical University, Shimotsuga 321-0293, Japan; siniho@dokkyomed.ac.jp

3 Department of Medicine, Division of Pulmonary Medicine, Jichi Medical University, Shimotsuke 329-0498, Japan; hagiwark@me.com

4 Department of Public Health, Jichi Medical University, Shimotsuke 329-0498, Japan; nakamuyk@jichi.ac.jp

5 Department of Surgery, National Hospital Organization Utsunomiya National Hospital, Utsunomiya 329-1193, Japan; norim0507@gmail.com

check for updates

Citation: Nomura, Y.; Sawahata, M.; Nakamura, Y.; Koike, R.; Katsube, O.; Hagiwara, K.; Niho, S.; Masuda, N.; Tanaka, T.; Sugiyama, K. Attenuation of Antibody Titers from 3 to 6 Months after the Second Dose of the BNT162b2 Vaccine Depends on Sex, with Age and Smoking Risk Factors for Lower Antibody Titers at 6 Months. Vaccines 2021, 9, 1500. https://doi.org/10.3390/vaccines 9121500

Academic Editor: Ger Rijkers

Received: 15 November 2021 Accepted: 15 December 2021 Published: 18 December 2021

Publisher's Note: MDPI stays neutral with regard to jurisdictional claims in published maps and institutional affiliations.

Copyright: () 2021 by the authors. Licensee MDPI, Basel, Switzerland. This article is an open access article distributed under the terms and conditions of the Creative Commons Attribution (CC BY) license (https:// creativecommons.org/licenses/by/ $4.0 /)$.
6 Department of Orthopaedic Surgery, National Hospital Organization Utsunomiya National Hospital, Utsunomiya 329-1193, Japan; tanaka.takaaki.vh@mail.hosp.go.jp

7 Saitama Medical Center, Department of Respiratory Medicine and Clinical Immunology, Dokkyo Medical University, Shimotsuga 321-0293, Japan

* Correspondence: sawahata@jichi.ac.jp; Tel.: +81-285587350

\begin{abstract}
Objective: We aimed to determine antibody titers at six months and their percentage change from three to six months after the second dose of the BNT162b2 coronavirus disease 2019 (COVID-19) mRNA vaccine (Pfizer/BioNTech) and to explore clinical variables associated with titers in Japan. Methods: We enrolled 365 healthcare workers ( 250 women, 115 men) whose three-month antibody titers were analyzed in our previous study and whose blood samples were collected $183 \pm 15$ days after the second dose. Participant characteristics, collected previously, were used. The relationships of these factors with antibody titers at six months and percentage changes in antibody titers from three to six months were analyzed. Results: Median age was 44 years. Median antibody titer at six months was $539 \mathrm{U} / \mathrm{mL}$. Older participants had significantly lower antibody titers (20s, $752 \mathrm{U} / \mathrm{mL}$; 60s-70s, $365 \mathrm{U} / \mathrm{mL}$ ). In age-adjusted analysis, smoking was the only factor associated with lower antibody titers. Median percentage change in antibody titers from three to six months was $-29.4 \%$. The only factor significantly associated with the percentage change in Ab titers was not age or smoking, but sex (women, $-31.6 \%$; men, $-25.1 \%$ ). Conclusion: The most important factors associated with lower antibody titers at six months were age and smoking, as at three months, probably reflecting their effect on peak antibody titers. However, the only factor significantly associated with the attenuation in $\mathrm{Ab}$ titers from three to six months was sex, which reduced the sex difference seen during the first three months. Antibody titers may be affected by different factors at different time points.
\end{abstract}

Keywords: SARS-CoV-2; viral infection; clinical epidemiology

\section{Introduction}

The BNT162b2 vaccine (Pfizer/BioNTech), which was the first coronavirus disease 2019 (COVID-19) mRNA vaccine to be administered to healthcare professionals in Japan, starting in February 2021, is expected to help to prevent both the onset [1] and progression of COVID-19. To obtain the maximum efficacy of vaccination with reduced adverse effects 
and to optimize and individualize the vaccination regimen, we need to record the exact chronological changes in real-world antibody $(\mathrm{Ab})$ titers following BNT162b2 vaccination and to investigate the relationships of recipients' medical histories and demographic characteristics with $\mathrm{Ab}$ titers.

Factors associated with the percentage change in $\mathrm{Ab}$ titers in the first few months after the second of the two BNT162b2 doses could differ from those associated with the peak $\mathrm{Ab}$ titers immediately after the second of the two BNT162b2 doses. The median titer shortly after the full schedule of this vaccine in Japan has been reported to be $2060 \mathrm{U} / \mathrm{mL}$ (interquartile range [IQR], 1250-2650 U/mL) [2], which is similar to the median titer reported in Italy (1975 U/mL; IQR, 895-3455 U/mL) [3]. Various factors, including older age [2,4-6], male sex [2], ethnicity [7], social condition [7], obesity [8,9], smoking habit [6,9], drinking habit [2], hypertension [9], cancer [10,11], and use of immunosuppressive drugs [2], have been reported to reduce the $\mathrm{Ab}$ titers obtained shortly after the second dose of the BNT162b2 vaccine. In Japan, older age, male sex, and drinking habit are reported risk factors for a lower peak value of the Ab titer [2].

In our previous cohort study of the serological $\mathrm{Ab}$ titers of 378 healthcare workers at 3 months after the second dose of the BNT162b2 vaccine [12] in Tochigi prefecture, Japan, these titers ranged from 3 to $5790 \mathrm{U} / \mathrm{mL}$, and the median (IQR) Ab titer was 764 (423-1140) U/mL, which was much lower than the above-mentioned value obtained shortly after the second inoculation. We thus determined that age and smoking status are predictors of $\mathrm{Ab}$ titers three months after the second dose of the BNT162b2 vaccine in Japan. However, the medium-term attenuation percentages of Ab titers several months after the second BNT162b2 dose and the relationship of these percentages with clinical background and demographic characteristics are still not known.

Against this background, we analyzed $\mathrm{Ab}$ titers at six months and their percentage change from three to six months after the second dose of the BNT162b2 vaccine and explored the clinical variables associated with these parameters in Japan. To investigate the $\mathrm{Ab}$ titers at three and six months, it is important to predict the period of effective $\mathrm{Ab}$ titers.

\section{Methods}

\subsection{Population and Study Design}

In this single-center prospective observational study, we recruited healthcare workers whose blood samples were collected $183 \pm 15$ days after the second of two BNT162b2 vaccine inoculations (Pfizer/BioNTech) administered 3 weeks apart in February and March 2021 in the National Hospital Organization Utsunomiya National Hospital in Tochigi prefecture, Japan.

Initially, we recruited 378 participants whose $\mathrm{Ab}$ titers 3 months after the second dose of the BNT162b2 COVID-19 vaccine were already analyzed in our previous study [12]. Their medical histories and demographic characteristics were recorded in that study using a structured self-report questionnaire [12]. Vaccination was voluntary, and all vaccinated individuals were included as participants. However, we excluded 13 participants, namely, 5 who had already moved from our hospital, 2 who were absent, 3 who declined to participate, and 3 whose blood sampling confirmed the presence of Abs against the nucleocapsid proteins for severe acute respiratory syndrome coronavirus 2 (SARS-CoV-2). Finally, we enrolled 365 healthcare workers (250 women, 115 men). After informed consent was obtained, we administered a questionnaire that covered personal information, such as smoking, drinking, complications, and medication.

Blood samples collected $183 \pm 15$ days after the second inoculation were used to measure total $\mathrm{Ab}$ titers against the SARS-CoV-2 spike antigen using a commercially available electrochemiluminescence immunoassay (ECLIA) (Elecsys®Anti-SARS-CoV-2 RUO; Roche Diagnostics) [13]. The relationships between Ab titers against the SARS-CoV-2 spike antigen and clinical and lifestyle characteristics were analyzed. In age-adjusted analysis, individual $\mathrm{Ab}$ titers were recalculated by subtracting the median $\mathrm{Ab}$ titer of the corresponding age group from an individual's Ab titer. For example, an age-adjusted Ab titer for an 
individual in his/her 20s was calculated as follows: individual Ab titer-median $\mathrm{Ab}$ titer for participants in their 20s.

In addition, we calculated the percentage change in Ab titers from 3 to 6 months after the second dose of the BNT162b2 COVID-19 vaccine. Individual percentage changes in $\mathrm{Ab}$ titers were calculated as follows: percentage change $=((\mathrm{Ab}$ titer 6 months after the $2 \mathrm{nd}$ dose $-\mathrm{Ab}$ titer 3 months after the 2nd dose [12])/ $\mathrm{Ab}$ titer 3 months after the 2nd dose) $\times 100(\%)$. Then, the relationships between these percentage changes in Ab titers against the SARS-CoV-2 spike antigen and clinical and lifestyle characteristics were analyzed.

The Ethics Committee of National Hospital Organization Utsunomiya National Hospital (No. 03-01; 19 April 2021) approved this study, and written informed consent was obtained from all participants before enrollment.

\subsection{Data Analysis}

Nonparametric continuous data are expressed as the median with the IQR. Categorical data are presented as absolute numbers and relative frequencies $(n, \%)$. To calculate Spearman's rank correlation coefficient and perform the Mann-Whitney $U$ test, we used Statistical Package for the Social Sciences (SPSS version 25). We considered $p$ values less than 0.05 to be statistically significant.

\section{Results}

\subsection{Study Population}

In total, 365 healthcare workers ( 250 women, 115 men) were enrolled in this study. Their baseline characteristics are summarized in Table 1. Briefly, the median (IQR) age and mean (SD) age of the participants was $44(32-54)$ years and $43.9( \pm 13.5)$ years, respectively. Nurses $(n=171)$ and physicians $(n=34)$ comprised $56.2 \%$ of the study population.

Table 1. Participants' baseline characteristics $(N=365)$.

\begin{tabular}{|c|c|c|c|c|}
\hline Variable & Total & $\begin{array}{l}\text { Ab Titer at } 6 \text { Months, } \\
\text { Median (IQR), U/mL }\end{array}$ & $\begin{array}{l}\text { Correlation } \\
\text { Coefficient } \rho\end{array}$ & $p$-Value \\
\hline Age, median (IQR), $y$ & $44(32-54)$ & & -0.347 & $<0.0001^{\#}$ \\
\hline $\operatorname{Sex}(\mathrm{M} / \mathrm{F}), n$ & $115 / 250$ & $\begin{array}{l}482(305 \text { to } 865) / \\
572(316 \text { to } 884)\end{array}$ & & 0.1970 * \\
\hline $\begin{array}{l}\text { Body mass index, median (IQR), } \\
\qquad \mathrm{kg} / \mathrm{m}^{2}\end{array}$ & $22.4(20.2-24.8)$ & & -0.017 & $0.7446^{\#}$ \\
\hline Smoking (ever/never), $n$ & $149 / 216$ & $\begin{array}{l}406(213 \text { to } 688) / \\
614 \text { (405 to } 957)\end{array}$ & & $<0.0001$ * \\
\hline \multirow[t]{3}{*}{$\begin{array}{c}\text { Current smoker/ } \\
\text { ex-smoker/unknown }\end{array}$} & $90 / 45 / 14$ & $\begin{array}{c}354(174 \text { to } 564) / \\
436(225 \text { to } 894) \S \S\end{array}$ & & 0.0609 * \\
\hline & & $\begin{array}{l}\text { ex-smoker vs. } \\
\text { never-smoker }\end{array}$ & & $0.0014 *$ \\
\hline & & $\begin{array}{l}\text { current smoker vs. } \\
\text { never-smoker }\end{array}$ & & $<0.0001$ * \\
\hline Brinkman Index $\S \S, \S \S \S, n$ & 129 & & -0.197 & $0.0258^{\#}$ \\
\hline Drinking, $n$ & $228 / 134 / 3 \S$ & $\begin{array}{l}544(299 \text { to } 881) / \\
536(348 \text { to } 868) \S \S\end{array}$ & & $0.7697^{*}$ \\
\hline \multicolumn{5}{|l|}{ Allergy, $n$} \\
\hline Food & $38 / 292 / 35^{\S}$ & $\begin{array}{l}515(307 \text { to } 925) / \\
544(318 \text { to } 807) \S \S\end{array}$ & & $0.7697^{*}$ \\
\hline Drug & $37 / 293 / 35 \S$ & $\begin{array}{c}517(287 \text { to } 759) / \\
549(321 \text { to } 833) \S \S\end{array}$ & & $0.5858 *$ \\
\hline
\end{tabular}


Table 1. Cont.

\begin{tabular}{|c|c|c|c|c|}
\hline Variable & Total & $\begin{array}{l}\text { Ab Titer at } 6 \text { Months, } \\
\text { Median (IQR), U/mL }\end{array}$ & $\begin{array}{l}\text { Correlation } \\
\text { Coefficient } \rho\end{array}$ & $p$-Value \\
\hline $\begin{array}{c}\text { Allergic disease, } n \\
\text { Allergic rhinitis } \\
\text { including pollinosis }\end{array}$ & $167 / 175 / 23 \S$ & $\begin{array}{c}546(258 \text { to } 895) / 523 \\
\text { (320 to } 792) \& \S\end{array}$ & & 0.8242 * \\
\hline Bronchial asthma & $43 / 299 / 23 \S$ & $\begin{array}{l}582(360 \text { to } 885) / \\
522304 \text { to } 837) \& \S\end{array}$ & & 0.5643 * \\
\hline $\begin{array}{l}\text { Skin allergy including } \\
\text { atopic dermatitis }\end{array}$ & $47 / 295 / 23 \S$ & $\begin{array}{l}641(380 \text { to } 1005) / \\
522(303 \text { to } 815) \S \S\end{array}$ & & 0.0710 * \\
\hline Diabetes mellitus, $n$ & $12 / 340 / 13 \S$ & $\begin{array}{l}331(149 \text { to } 589) / \\
540(318 \text { to } 878) \S \S\end{array}$ & & 0.0512 * \\
\hline Hypertension, $n$ & $27 / 325 / 13 \S$ & $\begin{array}{l}356(195 \text { to } 566) / \\
553(321 \text { to } 872) \& \S\end{array}$ & & 0.0327 * \\
\hline Dyslipidemia, $n$ & $18 / 334 / 13^{\S}$ & $\begin{array}{c}351(205 \text { to } 698) / \\
544(317 \text { to } 877) \S \S\end{array}$ & & 0.0834 * \\
\hline Collagen disease, $n$ & $13 / 332 / 20 \S$ & $\begin{array}{c}303(126 \text { to } 840) / \\
544(324 \text { to } 843) \S \S\end{array}$ & & 0.2695 * \\
\hline
\end{tabular}

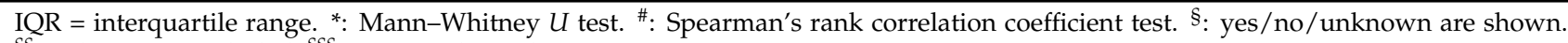
$\S \S$ : unknown is excluded. $\S \S \S$ : ever-smoker only.

3.2. Distribution of Ab Titers against the SARS-CoV-2 Spike Sntigen 6 Sonths after the Second Dose of the BNT162b2 COVID-19 Vaccine by Age and Sex

The median (IQR) Ab titer against the SARS-CoV-2 spike antigen 6 months after vaccination with the BNT162b2 COVID-19 vaccine was 539 (309-872) U/mL. Older participants had significantly lower SARS-CoV-2 Ab titers (correlation coefficient $\rho=-0.347$ ) (Table 1 and Figure 1). Ab titers tended to decrease in both men and women as participants' age increased from their 20s to 70s. Median antibody titers of men in their 20s, 30s, 40s, 50s, and 60s-70s were 823, 648, 485, 335, and $432 \mathrm{U} / \mathrm{mL}$, respectively, whereas median $\mathrm{Ab}$ titers of women in their 20s, 30s, 40s, 50s, and 60s-70s were 748, 641, 560, 490, and $318 \mathrm{U} / \mathrm{mL}$, respectively.

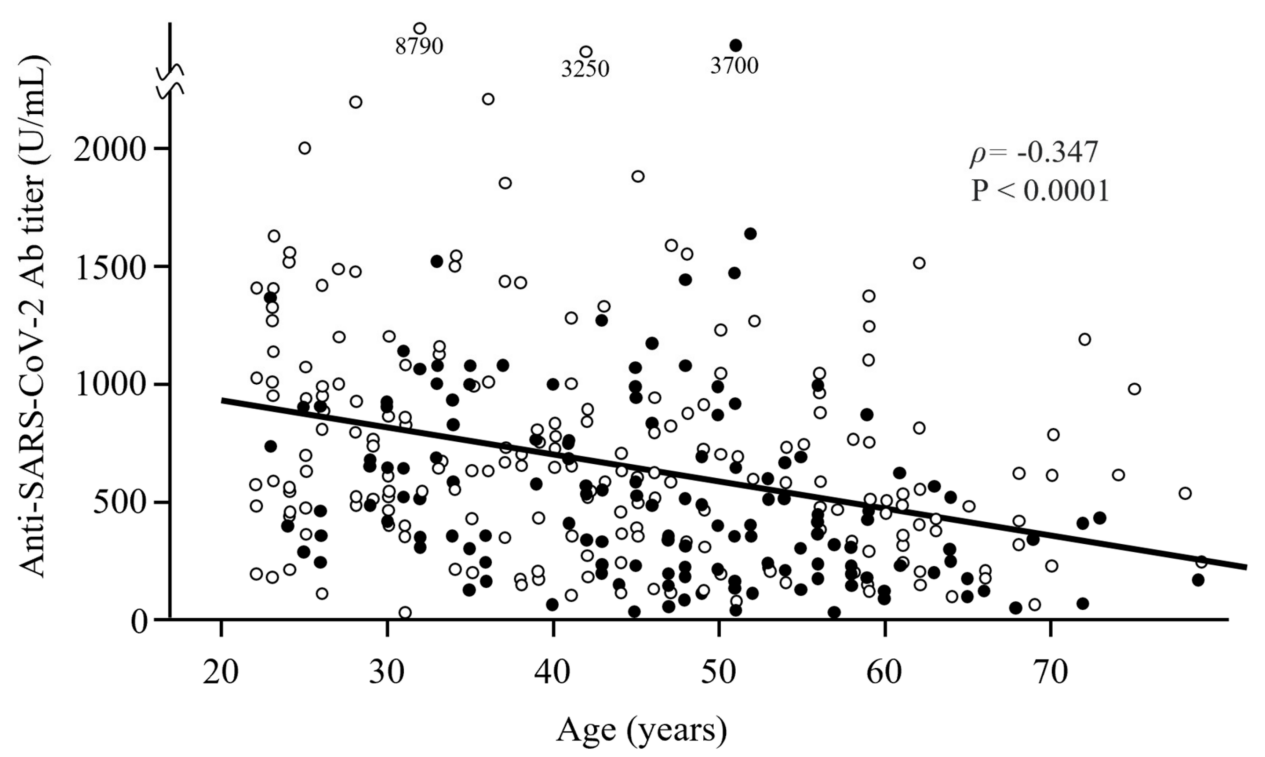

Figure 1. Scatter plot of the distribution of $A b$ titers 6 months after the second vaccine dose according to age and smoking status. Older participants had significantly lower Ab titers. Closed and open circles show ever-smokers and never-smokers, respectively. Ever-smokers had lower Ab titers than never-smokers. 


\subsection{Relationship between the Ab Titers against the SARS-CoV-2 Spike Antigen 6 Months after Vaccination and Risk Factors}

We first performed univariate analyses to identify factors associated with serum $\mathrm{Ab}$ titers against the SARS-CoV-2 spike protein. The factors significantly associated with lower $\mathrm{Ab}$ titers were older age, smoking, and hypertension (Table 1). Ever-smokers tended to have lower $\mathrm{Ab}$ titers than never-smokers (Figure 1 ).

We also analyzed the risk factors for lower $\mathrm{Ab}$ titers after adjustment for age because the prevalence of certain factors may differ according to age, such as hypertension. In the age-adjusted analysis, individual Ab titers were recalculated by subtracting the median $\mathrm{Ab}$ titer of the corresponding age group from an individual's Ab titer. Median Ab titers of participants in their 20s, 30s, 40s, 50s, and 60s-70s were 752, 642, 550, 418, and $365 \mathrm{U} / \mathrm{mL}$, respectively. Thus, the age-adjusted Ab titer for an individual in his/her 20s was calculated as "individual $\mathrm{Ab}$ titer-752". After age adjustment, the only factor significantly associated with lower $\mathrm{Ab}$ titers was smoking (Table 2 ). In terms of smoking, the age-adjusted median (IQR) Ab titers were -97 ( -277 to 184$)$ and 56 ( -182 to 342$)$ in ever-smokers and neversmokers, respectively.

Table 2. Age-adjusted data of median Ab titers $(N=365)$.

\begin{tabular}{|c|c|c|c|}
\hline Variable & $\begin{array}{c}\text { Ab Titer at } 6 \text { Months, Median (IQR), } \\
\text { U/mL }\end{array}$ & $\begin{array}{l}\text { Correlation } \\
\text { Coefficient } \rho\end{array}$ & $p$-Value \\
\hline Male/female & $-15(-246$ to 241$) / 8$ ( -209 to 290$)$ & & $0.2851 *$ \\
\hline Body mass index, median (IQR), $\mathrm{kg} / \mathrm{m}^{2}$ & & 0.023 & $0.6647^{\#}$ \\
\hline Smoking (ever/never) & $-97(-277$ to 184$) / 56$ ( -182 to 342$)$ & & $<0.0001$ * \\
\hline Current smoker/ex-smoker & $-205(-320$ to 7$) /-72(-264$ to 256$)$ & & $0.0255 *$ \\
\hline & ex-smoker vs. never-smoker & & $0.0203 *$ \\
\hline & current smoker vs. never-smoker & & $<0.0001 *$ \\
\hline Brinkman Index $\S \S, \S \S \S$ & & 0.012 & $0.8935^{\#}$ \\
\hline Drinking & $3(-242$ to 296$) / 5(-205$ to 249$) \S, \S \S$ & & $0.6475 *$ \\
\hline \multicolumn{4}{|l|}{ Allergy } \\
\hline Food & $18(-250$ to 235$) /-2(-223$ to 256$) \S, \S \S$ & & 0.9604 * \\
\hline Drug & $-4(-131$ to 271$) /-1(-238$ to 251$) \S, \S \S$ & & $0.5858 *$ \\
\hline Allergic disease & & & \\
\hline Allergic rhinitis including pollinosis & $-7(-240$ to 271$) /-1(-223$ to 253$) \S, \S \S$ & & 0.8473 * \\
\hline Bronchial asthma & $30(-223$ to 254$) /-8(-239$ to 263$) \S, \S \S$ & & $0.7390 *$ \\
\hline Skin allergy including atopic dermatitis & $61(-166$ to 421$) /-9(-240$ to 248$) \S, \S \S$ & & $0.1638 *$ \\
\hline Diabetes mellitus & $-60(-269$ to 77$) / 0(-225$ to 272$) \S, \S \S$ & & $0.4696 *$ \\
\hline Hypertension & $-69(-247$ to 183$) / 0(-225$ to 271$) \S, \S \S$ & & $0.6409 *$ \\
\hline Dyslipidemia & $-56(-220$ to 259$) / 0(-232$ to 268$) \S, \S \S$ & & $0.7392 *$ \\
\hline Collagen disease & $-227(-368$ to 290$) / 0(-222$ to 261$) \S, \S \S$ & & $0.3021 *$ \\
\hline
\end{tabular}

IQR = interquartile range. *: Mann-Whitney $U$ test. \#: Spearman's rank correlation coefficient test. $\$$ : yes/no are shown. $\$ \&$ : unknown is excluded. $\$ \S \&$ : ever-smoker only.

3.4. Distribution of the Percentage Change in Ab Titers from 3 to 6 Months after the Second Dose of the BNT162b2 COVID-19 Vaccine by Age and Sex

The median (IQR) percentage change in Ab titers against the SARS-CoV-2 spike antigen from three to six months after vaccination was $-29.4 \%(-40.4 \%$ to $-17.7 \%)$. No significant correlation was observed between the percentage change in the anti-SARS-CoV$2 \mathrm{Ab}$ titer and age (correlation coefficient $\rho=-0.028$ ) (Table 3 and Figure 2A). Median percentage changes in $\mathrm{Ab}$ titers of men in their 20s, 30s, 40s, 50s, and 60s-70s were -24.3 , $-25.3,-24.0,-33.7$, and $-14.8 \mathrm{U} / \mathrm{mL}$, respectively, whereas those of women in their 20s, $30 \mathrm{~s}, 40 \mathrm{~s}, 50 \mathrm{~s}$, and $60 \mathrm{~s}-70 \mathrm{~s}$ were $-33.8,-31.5,-31.5,-30.0$, and $-32.6 \mathrm{U} / \mathrm{mL}$, respectively. Surprisingly, the only factor significantly associated with the percentage change in the $\mathrm{Ab}$ 
titer was not age or smoking, but sex (Table 3). In terms of sex, median (IQR) percentage changes in $\mathrm{Ab}$ titers were $-31.6 \%(-42.0 \%$ to $-20.2 \%)$ and $-25.1 \%(-36.8 \%$ to $-12.0 \%)$ in women and men, respectively (Table 3), suggesting that Ab titers decrease faster in women than in men.

An additional analysis was performed (Table 4) because smoking was an important risk factor at both three and six months after vaccination and the smoking percentages differed between men and women. For age-adjusted median Ab titers, no significant sex differences were observed in the ever-smoker and never-smoker groups. However, both the male and female groups showed significant differences by smoking status in age-adjusted median $\mathrm{Ab}$ titers. On the other hand, no significant differences in the median percentage change in $\mathrm{Ab}$ titers by smoking status were observed in the male and female groups. However, both the ever-smoker and never-smoker groups showed significant sex differences in the median percentage change in $\mathrm{Ab}$ titers.

The relationship between the percentage changes in $\mathrm{Ab}$ titers and the $\mathrm{Ab}$ titer 6 months after vaccination was analyzed (Figure 2B). A significant positive correlation was observed, indicating that participants with a lower $\mathrm{Ab}$ titer had greater attenuation of the $\mathrm{Ab}$ titer.

Table 3. Median percentage change in Ab titers from 3 months to 6 months $(N=365)$.

\begin{tabular}{|c|c|c|c|}
\hline Variable & $\begin{array}{c}\text { Percentage Change in Ab Titers, } \\
\text { Median (IQR), } \% \S\end{array}$ & $\begin{array}{l}\text { Correlation } \\
\text { Coefficient } \rho\end{array}$ & $p$-Value \\
\hline Age & & -0.028 & $0.5876^{\#}$ \\
\hline Male/female & $-25.1(-36.8$ to -12.0$) /-31.6(-42.0$ to -20.2$)$ & & $0.0005 *$ \\
\hline Body mass index, median (IQR), $\mathrm{kg} / \mathrm{m}^{2}$ & & 0.025 & $0.6274^{\#}$ \\
\hline Smoking (ever/never) & $-28.4(-39.7$ to -15.5$) /-30.3(-40.7$ to -19.0$)$ & & 0.3051 * \\
\hline Current smoker/ex-smoker & $-31.7(-40.6$ to -18.3$) /-27.4(-40.1$ to -16.1$) \S \S$ & & $0.3853 *$ \\
\hline & ex-smoker vs. never-smoker & & 0.2914 * \\
\hline & current smoker vs. never-smoker & & 0.8809 * \\
\hline Brinkman Index $\S \S, \S \S \S$ & & -0.034 & $0.6990^{\#}$ \\
\hline Drinking & $-29.1(-41.0$ to -17.8$) /-30.5(-39.1$ to -18.1$) \S, \S \S$ & & $0.777 *$ \\
\hline \multicolumn{4}{|l|}{ Allergy } \\
\hline Food & $-29.4(-37.1$ to -16.5$) /-29.4(-39.9$ to -18.6$) \S, \S \S$ & & 0.7821 * \\
\hline Drug & $-28.8(-40.7$ to -22.6$) /-29.7(-39.3$ to -18.3$) \S, \S \S$ & & 0.7469 * \\
\hline Allergic disease & & & \\
\hline Allergic rhinitis including pollinosis & $-29.2(-40.9$ to -18.1$) /-29.6(-39.6$ to -18.0$) \S, \S \S$ & & 0.8606 * \\
\hline Bronchial asthma & $-31.7(-40.5$ to -19.4$) /-29.1(-40.5$ to -17.6$) \S, \S \S$ & & 0.5521 * \\
\hline Skin allergy including atopic dermatitis & $-30.3(-44.6$ to -25.1$) /-29.1(-39.7$ to -17.6$) \S, \S \S$ & & $0.1677 *$ \\
\hline Diabetes mellitus & $-27.6(-32.8$ to -11.4$) /-29.4(-40.5$ to -18.0$) \S, \S \S$ & & $0.3617 *$ \\
\hline Hypertension & $-24.0(-32.1$ to -12.3$) /-29.7(-40.8$ to -18.0$) \S, \S \S$ & & $0.0679 *$ \\
\hline Dyslipidemia & $-31.7(-39.2$ to -22.8$) /-29.3(-40.5$ to -17.7$) \S, \S \S$ & & 0.7178 * \\
\hline Collagen disease & $-27.0(-48.6$ to -19.1$) /-29.6(-40.3$ to -17.9$) \S, \S \S$ & & $0.889 *$ \\
\hline
\end{tabular}

IQR = interquartile range. *: Mann-Whitney $U$ test. \#: Spearman's rank correlation coefficient test. ${ }^{\S}$ : yes/no are shown. $\$ \S$ : unknown is excluded. $\$ \S \S$ : ever-smoker only. 

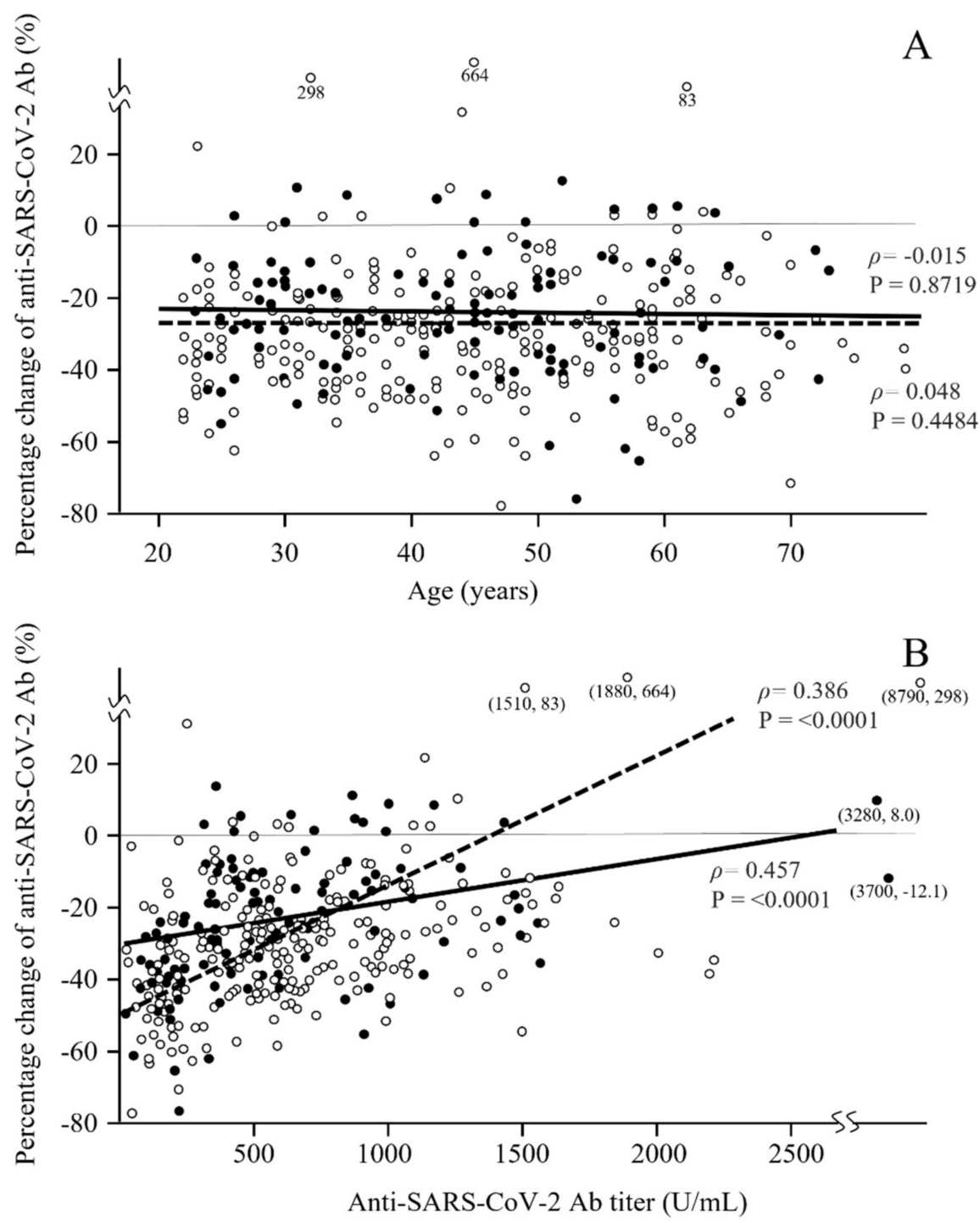

Figure 2. Scatter plot of the distribution of the percentage change in Ab titers from 3 to 6 months after the second dose of the vaccine according to sex. The relationship between the percentage change after the vaccination and age is shown in (A), and the relationship between the percentage change and the $\mathrm{Ab}$ titer 6 months after the vaccination is shown in (B). No significant correlation was observed in (A), and age did not affect the attenuation of the $\mathrm{Ab}$ titers from 3 to 6 months after the vaccination. However, a significant correlation was observed in (B). Closed and open circles and continuous and broken lines show men and women, respectively. 
Table 4. Age-adjusted median $\mathrm{Ab}$ titers and percentage changes in the relationship between sex and smoking.

\begin{tabular}{|c|c|c|c|}
\hline Variable & $\begin{array}{c}\text { Male } n, \\
\text { Ab, Median (IQR), U/mL } \\
\text { Percentage Change, Median (IQR), } \\
\%\end{array}$ & $\begin{array}{c}\text { Female } n, \\
\text { Ab, Median (IQR), U/mL } \\
\text { Percentage Change, Median (IQR), } \\
\%\end{array}$ & $\begin{array}{c}p \text {-Value for } \\
\text { Ab Titer } \\
\text { Percentage Change }\end{array}$ \\
\hline Ever-smokers & $\begin{array}{c}70 \\
-120(-266 \text { to } 152) \\
-25.9 \%(-38.0 \text { to }-12.0)\end{array}$ & $\begin{array}{c}79 \\
-68(-278 \text { to } 193) \\
-30.5 \%(-42.0 \text { to }-18.7)\end{array}$ & $\begin{array}{l}0.5709 * \\
0.0400 *\end{array}$ \\
\hline Never-smokers & $\begin{array}{c}45 \\
115(-181 \text { to } 519) \\
-24.0 \%(-34.0 \text { to }-12.1)\end{array}$ & $\begin{array}{c}171 \\
46(-181 \text { to } 332) \\
-31.7 \%(-42.1 \text { to }-20.9)\end{array}$ & $\begin{array}{l}0.4700 * \\
0.0050 \text { * }\end{array}$ \\
\hline $\begin{array}{c}\text { p-value for } \\
\text { Ab titer } \\
\text { Percentage change }\end{array}$ & $\begin{array}{l}0.0040 \text { * } \\
0.7613 \text { * }\end{array}$ & $\begin{array}{l}0.0120 \text { * } \\
0.7018 \text { * }\end{array}$ & \\
\hline
\end{tabular}

IQR = interquartile range. *: Mann-Whitney $U$ test.

\section{Discussion}

To our knowledge, this is the first study to report real-world $\mathrm{Ab}$ titers against the SARS-CoV-2 spike antigen at six months and the percentage changes in Ab titers from three to six months after vaccination and to identify the factors associated with these parameters from a comprehensive range of clinical and lifestyle characteristics in Japan. Few studies have examined this issue [14,15]. Four important findings were obtained. First, in a cohort with a median (IQR) age of $44(32-54)$ years, the median $\mathrm{Ab}$ titer six months after the second dose was $539 \mathrm{U} / \mathrm{mL}$. Older participants had significantly lower Ab titers, with an $\mathrm{Ab}$ titer about half that of those in their 20s. Second, in an age-adjusted analysis, the only risk factor for a lower $\mathrm{Ab}$ titer was smoking. Third, the median percentage change in the $\mathrm{Ab}$ titer from three to six months after vaccination was $-29.4 \%$. Surprisingly, the only factor significantly associated with attenuation of the Ab titers was not age or smoking, but sex. The median percentage changes in Ab titers were $-31.6 \%$ and $-25.1 \%$ in women and men, respectively. Fourth, both male and female participants with a lower Ab titer showed greater attenuation of the $\mathrm{Ab}$ titer. This means that the percentage change in $\mathrm{Ab}$ titers may be affected by individual differences.

In terms of the first and second findings, the most important factors associated with a low $\mathrm{Ab}$ titer six months after the second dose were still age and smoking habit, as seen three months after the second dose, probably reflecting their effect on peak Ab titers. Interestingly, a reversal of the sex difference in $\mathrm{Ab}$ titers seen three months after the second dose was observed at six months. In our previous study, the median Ab titer was $764 \mathrm{U} / \mathrm{mL}$ three months after the second dose [12]. The median Ab titers were 942 and $1095 \mathrm{U} / \mathrm{mL}$ in men and women in their 20s, respectively, but 490 and $519 \mathrm{U} / \mathrm{mL}$ in men and women in their 60s-70s, respectively. In the age-adjusted analysis, the only risk factors for a lower $\mathrm{Ab}$ titer three months after the second dose [12] were male sex and smoking. However, we concluded that the sex difference may have arisen from the sex difference in the smoking percentage, rather than from biological sex differences. We found several studies reporting an association between smoking and lower Ab titers against both influenza virus [16] and hepatitis B virus [17] after vaccination, although the actual mechanisms are poorly understood.

Regarding the third finding, the only factor significantly associated with the attenuation in $\mathrm{Ab}$ titers from three to six months after the second dose was not age or smoking, but sex, which seemingly resulted in a reduction of the sex difference in Ab titers seen three months after the second dose. This suggests that $\mathrm{Ab}$ titers decrease faster in women than in men.

Concerning the fourth finding, we hypothesized that participants with a higher $\mathrm{Ab}$ titer would show greater attenuation of Ab titers because the percentage change from three to six months and the $\mathrm{Ab}$ titer three months after vaccination were significantly higher in 
women than in men. However, a significant positive correlation was observed between the percentage change in $\mathrm{Ab}$ titers and the $\mathrm{Ab}$ titer six months after vaccination. The $\mathrm{Ab}$ titer at six months after vaccination was associated with the percentage attenuation from three to six months, and participants with a lower $\mathrm{Ab}$ titer showed greater attenuation of the titer. We could not find other risk factors, such as age and comorbidities, beyond the above. Although we concluded that the attenuation was affected by individual differences, we will continue to define the risk factors through additional study.

The factors identified to affect $\mathrm{Ab}$ titers vary by the time elapsed since vaccination. For peak $\mathrm{Ab}$ titers 2-5 weeks after vaccination, the reported risk factors were sex, age, and alcohol intake. Three months after vaccination, age and smoking were risk factors in our study, and the effects of sex and alcohol intake were not observed. Six months after vaccination, age and smoking were still risk factors in our study. However, these factors did not affect the attenuation from three to six months. This means that these factors will strongly affect the $\mathrm{Ab}$ titer within three months after vaccination and that the effects will persist six months after vaccination. From three to six months after vaccination, sex and lower $\mathrm{Ab}$ titer were risk factors. According to the above results, smoking is the most important factor that could be avoided to maintain a higher Ab titer. Thus, it appears that different factors affect the $\mathrm{Ab}$ titer at different time points.

Some limitations and possible sources of bias in this study include the following. First, the participants were limited in number and were all healthcare workers vaccinated at a single national hospital in Tochigi prefecture. Therefore, the results obtained in this study might not be generalizable on a wide scale, or even within Japan. Second, we excluded participants with Abs against nucleocapsid proteins on the presumption that they had previously been infected with COVID-19. However, some of these patients had slight increases in $\mathrm{Ab}$ titers against the spike protein but became negative for $\mathrm{Ab}$ titers against nucleocapsid proteins. One possibility is that they had not been infected with COVID-19 and that the Ab titers against the spike protein had been increased by individual differences. The other possibility is that the $\mathrm{Ab}$ titers against nucleocapsid proteins might have not increased due to a small viral load of SARS-CoV-2, even though they may still have been infected with COVID-19. To determine the chance of exposure to a small amount of SARS-CoV-2 virus, we analyzed Ab titers in participants who worked in the COVID-19 ward (data not shown). However, their $\mathrm{Ab}$ titers were not increased. If the excluded participants were by chance exposed to a small amount of SARS-CoV-2 virus, it may have been through daily life and not the COVID-19 ward. In addition, five participants had $\mathrm{Ab}$ titers exceeding $3000 \mathrm{U} / \mathrm{mL}$ and/or a greater than $80 \%$ increase in $\mathrm{Ab}$ titers against the spike protein, despite negative Abs against nucleocapsid proteins. They may have been infected with COVID-19, considering that a participant with an Ab titer against spike proteins exceeding $5000 \mathrm{U} / \mathrm{mL}$ and without $\mathrm{Ab}$ titers against nucleocapsid proteins three months after vaccination had positive $\mathrm{Ab}$ titers against nucleocapsid proteins at six months. The participant may have been infected with COVID-19 three months after vaccination and the Abs against nucleocapsid proteins may have increased at a late stage due to the infection. However, we do not have evidence that the above five participants were infected with COVID-19 and we did not exclude them from our analysis.

In conclusion, the most important factors associated with a low $\mathrm{Ab}$ titer six months after the second dose were age and smoking habit, as seen three months after the second dose, probably reflecting the effects of these factors on peak $\mathrm{Ab}$ titers. However, the attenuation of $\mathrm{Ab}$ titers from three to six months after the second BNT162b2 dose depended not on age or smoking, but on sex. A significant attenuation of Ab titers from three to six months was solely observed in women and resulted in a reduction of the sex difference in the $\mathrm{Ab}$ titer seen at three months. Further studies of the associations between $\mathrm{Ab}$ titers and the comprehensive medical histories of individuals are needed to establish a more personalized approach to vaccination involving earlier boosters, different schedules, or different types of vaccines. 
Author Contributions: Conceptualization, M.S., K.S., Y.N. (Yushi Nomura) and Y.N. (Yosikazu Nakamura); methodology and software, Y.N. (Yushi Nomura), K.S., M.S. and Y.N. (Yosikazu Nakamura); validation, K.S., M.S. and Y.N. (Yosikazu Nakamura); formal analysis and investigation, K.S., Y.N. (Yushi Nomura), M.S. and Y.N. (Yosikazu Nakamura); resources, T.T., K.S., N.M., Y.N. (Yushi Nomura), M.S., O.K. and R.K.; data curation, Y.N. (Yushi Nomura), K.S. and M.S.; writing-original draft preparation, M.S., K.S., Y.N. (Yushi Nomura) and Y.N. (Yosikazu Nakamura); writing-review and editing, T.T., N.M., S.N., K.H., O.K. and R.K.; visualization, K.S., Y.N. (Yushi Nomura) and M.S.; supervision, M.S., K.S., T.T., S.N. and K.H.; project administration, K.S. and T.T.; funding acquisition, T.T. and K.S. All authors have read and agreed to the published version of the manuscript.

Funding: This research received no external funding.

Institutional Review Board Statement: The study was conducted according to the guidelines of the Declaration of Helsinki and approved by the Ethics Committee of National Hospital Organization Utsunomiya National Hospital (No. 03-01, 19 April 2021).

Informed Consent Statement: Informed consent was obtained from all subjects involved in the study.

Acknowledgments: The authors thank all staff at National Hospital Organization Utsunomiya National Hospital for providing support during sample collection. We would like to thank Miwa Okada, Junko Shibayama, Yuko Tajima, Mami Ochiai, Midori Takahashi, Hiroko Ueno, Natsuka Suzuki, and Yoshino Iwaya for providing support during data analysis.

Conflicts of Interest: The authors declare no conflict of interest.

\section{Abbreviations}

COVID-19: coronavirus disease 2019; Ab: antibody; IQR: interquartile range; SARS-CoV-2: severe acute respiratory syndrome coronavirus 2.

\section{References}

1. Nomura, Y.; Sawahata, M.; Nakamura, Y.; Kurihara, M.; Koike, R.; Katsube, O.; Hagiwara, K.; Niho, S.; Masuda, N.; Tanaka, T; et al. Age and smoking predict antibody titres at 3 months after the second dose of the BNT162b2 COVID-19 vaccine. Vaccines 2021, 9, 1042. [CrossRef] [PubMed]

2. $\quad$ Perkmann, T.; Perkmann-Nagele, N.; Breyer, M.K.; Breyer-Kohansal, R.; Burghuber, O.C.; Hartl, S.; Aletaha, D.; Sieghart, D.; Quehenberger, P.; Marculescu, R.; et al. Side-by-side comparison of three fully automated SARS-CoV-2 antibody assays with a focus on specificity. Clin. Chem. 2020, 66, 1405-1413. [CrossRef]

3. Kageyama, T.; Ikeda, K.; Tanaka, S.; Taniguchi, T.; Igari, H.; Onouchi, Y.; Kaneda, A.; Matsushita, K.; Hanaoka, H.; Nakada, T.; et al. Antibody responses to BNT162b2 mRNA COVID-19 vaccine and their predictors among healthcare workers in a tertiary referral hospital in Japan. Clin. Microbiol. Infect. 2021, 27, 1861. [CrossRef]

4. Callegaro, A.; Borleri, D.; Farina, C.; Napolitano, G.; Valenti, D.; Rizzi, M.; Maggiolo, F. Antibody response to SARS-CoV-2 vaccination is extremely vivacious in subjects with previous SARS-CoV-2 infection. J. Med. Virol. 2021, 93, 4612-4615. [CrossRef] [PubMed]

5. Müller, L.; Andrée, M.; Moskorz, W.; Drexler, I.; Walotka, L.; Grothmann, R.; Ptok, J.; Hillebrandt, J.; Ritchie, A.; Rabl, D.; et al. Age-dependent immune response to the Biontech/Pfizer BNT162b2 COVID-19 vaccination. Clin. Infect. Dis. 2021, 73, $2065-2072$. [CrossRef] [PubMed]

6. Terpos, E.; Trougakos, I.P.; Apostolakou, F.; Charitaki, I.; Sklirou, A.D.; Mavrianou, N.; Papanagnou, E.-D.; Liacos, C.-I.; Gumeni, S.; Rentziou, G.; et al. Age-dependent and gender-dependent antibody responses against SARS-CoV-2 in health workers and octogenarians after vaccination with the BNT162b2 mRNA vaccine. Am. J. Hematol. 2021, 96, 257-259. [CrossRef] [PubMed]

7. Kennedy, N.A.; Lin, S.; Goodhand, J.R.; Chanchlani, N.; Hamilton, B.; Bewshea, C.; Nice, R.; Chee, D.; Cummings, J.F.; Fraser, A.; et al. Infliximab is associated with attenuated immunogenicity to BNT162b2 and ChAdOx1 nCoV-19 SARS-CoV-2 vaccines in patients with IBD. Gut 2021, 70, 1884-1893. [CrossRef] [PubMed]

8. Wei, J.; Stoesser, N.; Matthews, P.C.; Ayoubkhani, D.; Studley, R.; Bell, I.; Bell, J.I.; Newton, J.N.; Farrar, J.; Diamond, I.; et al. COVID-19 Infection Survey team. Antibody responses to SARS-CoV-2 vaccines in 45,965 adults from the general population of the United Kingdom. Nat. Microbiol. 2021, 6, 1140-1149. [CrossRef] [PubMed]

9. Ledford, H. How obesity could create problems for a COVID vaccine. Nature 2020, 586, 488-489. [CrossRef] [PubMed]

10. Watanabe, M.; Balena, A.; Tuccinardi, D.; Tozzi, R.; Risi, R.; Masi, D.; Caputi, A.; Rossetti, R.; Spoltore, M.E.; Filippi, V.; et al. Central obesity, smoking habit, and hypertension are associated with lower antibody titres in response to COVID-19 mRNA vaccine. Diabetes Metab. Res. Rev. 2021. [CrossRef] [PubMed] 
11. Collier, D.A.; Ferreira, I.A.T.M.; Kotagiri, P.; Datir, R.P.; Lim, E.Y.; Touizer, E.; Meng, B.; Abdullahi, A.; Elmer, A.; Kingston, N.; et al. Age-related immune response heterogeneity to SARS-CoV-2 vaccine BNT162b2. Nature 2021, 596, 417-422. [CrossRef] [PubMed]

12. Monin-Aldama, L.; Laing, A.G.; Muñoz-Ruiz, M.; McKenzie, D.R.; del Molino del Barrio, I.; Alaguthurai, T.; Domingo-Vila, C.; Hayday, T.S.; Graham, C.; Cooper, J.; et al. Interim results of the safety and immune-efficacy of 1 versus 2 doses of COVID-19 vaccine BNT162b2 for cancer patients in the context of the UK vaccine priority guidelines. medRxiv 2021. [CrossRef]

13. Bergwerk, M.; Gonen, T.; Lustig, Y.; Amit, S.; Lipsitch, M.; Cohen, C.; Mandelboim, M.; Levin, E.G.; Rubin, C.; Indenbaum, V.; et al. Covid-19 Breakthrough Infections in Vaccinated Health Care Workers. N. Engl. J. Med. 2021, 385, 1474-1484. [CrossRef] [PubMed]

14. L'Huillier, A.G.; Meyer, B.; Andrey, D.O.; Vernez, I.A.; Baggio, S.; Didierlaurent, A.; Eberhardt, C.S.; Eckerle, I.; Salomon, C.G.; Huttner, A.; et al. Antibody persistence in the first 6 months following SARS-CoV-2 infection among hospital workers: A prospective longitudinal study. Clin. Microbiol. Infect. 2021, 27, 784. [CrossRef]

15. Naaber, P.; Tserel, L.; Kangro, K.; Sepp, E.; Jürjenson, V.; Adamson, A.; Haljasmägi, L.; Rumm, A.P.; Maruste, R.; Maruste, R.; et al. Dynamics of antibody response to BNT162b2 vaccine after six months: A longitudinal prospective study. Lancet Reg. Health Eur. 2021, 10, 100208. [CrossRef]

16. MacKenzie, J.S.; MacKenzie, I.H.; Holt, P.G. The effect of cigarette smoking on susceptibility to epidemic influenza and on serological responses to live attenuated and killed subunit influenza vaccines. J. Hyg. 1976, 77, 409-417. [CrossRef] [PubMed]

17. Zimmermann, P.; Curtis, N. Factors that influence the immune response to vaccination. Clin. Microbiol. Rev. 2019, 32, e00084-18. [CrossRef] [PubMed] 